\title{
Criminal Liability Against The Criminal Act of Trafficting Children for The Purpose of Prostitution (Study of Decision No. 1.262/Pid. B/2008/PN. Mdn)
}

\section{Grace Eka Astuti Tamba}

Criminal Law Department, North Sumatera University Faculty Of Law. E-mail: graceeka@gmail.com

\begin{tabular}{l} 
ARTICLE INFO \\
\hline Keywords: \\
Criminal Liability Against, \\
The Purpose of Prostitution \\
Article history: \\
Received Jan 30, 2020; \\
Revised Mar 03, 2020; \\
Accepted Jun 13, 2020; \\
Online Jul 30, 2020. \\
\end{tabular}

\begin{abstract}
Trafficking in people for the purpose of prostitution is one of the fastest growing criminal activities in the world. This crime continues to grow nationally and internationally. Although men are also victims of trafficking, the majority of those trafficked are women and children who come from poor families in rural and urban slum areas. The way it works always involves brokers or agents. The brokers and agents are tasked with approaching victims in rural areas, crowds, cafes, and restaurants. Cases of crimes against women and children or trafficking, even though they have been handled, are expected to continue to increase. This condition is influenced by the still weak economic level for some regions and weak law enforcement. This is the reason behind the author's interest in writing a thesis with problems including what regulations are related to child trafficking and how is criminal responsibility for perpetrators of criminal acts of child trafficking for the purpose of prostitution. This thesis is a normative juridical research, by conducting library research and analyzing the decision of the Medan District Court in Case Register No. 1.262/ Pid. B/ 2008/ PN. Mdn.In Indonesia itself, the problem of prostitution is not a new thing. This can be seen from the era of the Javanese kingdoms which was growing during the colonial era. During the Dutch colonial era, the WvS (KUHP) was enacted which was also used by Indonesia. However, the Indonesian government feels that the articles in the Criminal Code cannot ensnare traffickers, then the government seeks a ban on child trafficking which has been stated in various laws and regulations, starting from Law no. 39 of 1999 until the enactment of Law No. 21 of 2007 on the Eradication of the Crime of Trafficking in Persons. Indonesia also participates at the international level, namely by ratifying various conventions, namely the Convention on the Rights of the Child in 1989 and the ILO Convention Number 182 in 1999. Regarding the concept of criminal responsibility for the perpetrators of the crime of trafficking in children for the purpose of prostitution, it is the same as criminal liability in general, namely that there must be errors and the ability to be responsible, where the implementation of the criminal provisions is seen from the tempus delicti.
\end{abstract}

This is an open access article under the CC BY-NC license.

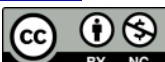

\section{Introduction}

Human Trafficking is a crime that is very difficult to eradicate and is touted by the international community as a form of modern slavery and a violation of human rights. This crime continues to grow nationally and internationally. Human Trafficking or trafficking in persons, especially women and children, is a type of slavery in this modern era. But along with looking for work, they are vulnerable to being trapped in human trafficking. Trafficking in 
persons, for whatever reason is also a serious violation of human rights. Trafficking of women and children does not only occur in Indonesia as a developing country, but also in other developing countries such as Vietnam, Sri Lanka, Thailand and the Philippines. This is the result of uncertainty and inability to face free competition from the concept of economic liberalism in the era of globalization, which has a fairly complex impact, especially on increasing the role and position of women in the economic field, both nationally and internationally.

In 2003 the Secretary-General of the United Nations commissioned representatives around the world to conduct a study on violence against children. Results reported in 20063 show that violence against children is a global problem. In all countries involved, children experience various forms of violence such as corporal punishment, forced labor or exploitation in a variety of hazardous occupations (mining, garbage, military, commercial sex, drug trafficking, etc.), discrimination, early marriage, and pornography. The sad thing is that some forms of violence and exploitation, such as corporal punishment and child labour, are gaining socio-cultural acceptance. Therefore, the Secretary-General of the United Nations urges people and governments around the world to act, respond, and Trafficking in persons usually occurs starting with deception, then treated inhumanely and exploited. The forms of exploitation include victims working which lead to sexual practices, slavery, and organ transplantation, to selling babies with the aim of making a profit. Cases of trafficking in persons in Indonesia, not only penetrated in Java, such as Indramayu, but also occurred in big cities such as Jakarta, Surabaya, Bali, Medan, Padang, Pontianak, Makassar and Manado which were recorded as areas of exploitation of children for commercial sex purposes.

If viewed from the legal aspect, syndicates like this have entered the area of criminal acts, the treatment of certain irresponsible parties in trafficking in persons (trafficking in person) is business orientation, without thinking that women and children are God's creatures that need to be protected and have rights. dignity that has rights and obligations as regulated in the 1945 Constitution of the Republic of Indonesia and Law no. 39 of 1999 concerning Human Rights.

The Crime of Trafficking in Persons (TPPO), especially women and children, has spread in the form of organized and unorganized crime networks. The network of perpetrators of the Crime of Trafficking in Persons has a range of operations not only between regions within the country but also between countries. Many victims of trafficking both domestically and internationally are intended for sexual exploitation (prostitution). Children are considered not yet able to make decisions for themselves, so that children who enter the world of prostitution can be ascertained as trafficking in persons.

In dealing with various cases concerning the Crime of Trafficking in Persons, the government has taken a firm stance, namely by enacting a number of laws and regulations to provide fulfillment, respect and protection from all forms of exploitation and discrimination, one of which is by ratifying the United Nations Convention on the Rights of the Child. (KHA) through Presidential Decree No. 36 of 1990 which became an important momentum in the efforts of the government and civil society in protecting children's rights. This convention is an international treaty or agreement that regulates the recognition, respect, and protection of the fundamental rights of children. In Article 32 all States parties are expected to protect the child from all forms of exploitation that harm the child's physical and morals.

The issue of sexual exploitation of children received a global response which was manifested in the World Congress to eliminate commercial sexual exploitation of children in Stockholm, Sweden in 1996. This meeting resulted in the Stockholm Agenda which contains various actions that need to be taken by participating countries including Indonesia. As a result of the global movement to eliminate the sexual exploitation of children, in 2000 the United Nations drafted an optional protocol specifically to tackle trafficking, pornography and child 
prostitution (Optional Protocol on the safe of children, child prostitution and child pornography) which was implemented in 2000. 2002. Indonesia has signed this optional protocol and according to the National Action Plan (RAN) on Human Rights 2004-2009 should have been ratified in 2005 but has not been implemented so far. However, it should be noted that Indonesia's commitment has been realized by building a national coalition and making a National Action Plan (RAN) which was ratified through Presidential Decree no. 87 of 2002 which was followed by the formulation of the NAP on trafficking in children and women through Presidential Decree no. 88 Years 20022.

Indonesia has indeed shown significant progress in demonstrating its commitment to combating sexual exploitation and child trafficking. This was realized with the issuance of the Child Protection Act no. 23 of 2002 and the Law on the Eradication of the Crime of Human Trafficking No. 21 of 2007. In addition, in 2005 a comprehensive policy was formulated which included children's problems as one of the main problems in national development. This policy document is called the National Development for Indonesian Children (PNBAI) 2015. This document outlines a medium-term development plan to improve the quality of health, education, HIV/AIDS prevention, and child protection including the need to develop laws and legal mechanisms to protect children from various forms of exploitation. as well as service facilities and infrastructure to help victims.

Various issues ranging from prevention, case management, recovery and reintegration of victims themselves are still facing problems because there are no specific laws and regulations that regulate trafficking in persons. In the Criminal Code (KUHP), the article that is often used as a basis for ensnaring traffickers is Article 297 which states "Trafficking in women and boys who are not old enough can be punished with a maximum sentence of six years." But in reality, the article that is often imposed is Article 378, namely a criminal act of fraud that can only ensnare recruiters.

\section{Method}

The research used is normative legal research, namely research on both legal principles and legal history as well as conducting an inventory of laws and regulations relating to the Crime of Child Trafficking for the purpose of prostitution and analyzing the decisions of the Medan District Court.

In writing this thesis, the method of data collection by Library Research is used, namely by conducting research on various reading sources such as books, opinions of scholars, newspapers, articles, dictionaries, and also data the authors obtain from the internet. .

\section{Analysis and Results.}

\subsection{National Legal Regulations}

Trafficking in children has been around for a long time and is an act that is against human dignity. This is a violation of human rights which is one of the problems that need urgent handling by all components of the nation. The problem of child trafficking is indeed a very complex problem that cannot be separated from economic, social, cultural, and political factors that are closely related to one another. Trafficking is one of the pathways for trafficking in persons, where the average victim is below the poverty line, especially children.

The government recognizes that trafficking in persons is a major problem and has taken steps to combat it as outlined in Law no. 23 of 2002 concerning Child Protection. Meanwhile, at the local government level, especially the North Sumatra provincial government, it pays special attention to trafficking in persons, namely by promulgating a North Sumatra Provincial 
Regulation no. 6 of 2004 concerning the Elimination of Trafficking in Women and Children. And after going through a very long process, in early 2007 Law no. 21 concerning the Eradication of the Crime of Trafficking in Persons.

\subsection{Law Number 23 of 2002 concerning Child Protection}

Commercial sexual exploitation of children includes criminal practices that demean and threaten the physical and psychosocial integrity of children. The Declaration and Agenda for Action against the Commercial Sexual Exploitation of Children60 is the first instrument to define commercial sexual exploitation of children as.

The presence of the Child Protection Law (UUPA) strengthens the implementation of the Convention on the Rights of the Child (CRC) in Indonesia. This law is based on four main principles of CRC: non-discrimination, the best for children, the right to live and develop and participate. The Child Protection Act provides a very useful umbrella framework to provide protection for the most vulnerable/vulnerable children. One of the strengths of this law is the existence of clear and firm sanctions against anyone who violates children's rights.

a. Rules Law International To Ban Child Trafficking

1) Convention on the Rights of the Child 1989 (Convention on The Right of The Child 1989)The Convention on the Rights of the Child was ratified by the General Assembly of the United Nations (UN) on November 20,1989, and entered into coercive power on September 2, 1990. This Convention on the Rights of the Child is an instrument that formulates principles -universal principles and legal norms regarding the position of children. Therefore, the Convention on the Rights of the Child is an international treaty on human rights that includes civil and political rights, economic, social and cultural rights, respectively. The Convention on the Rights of the Child is the result of consultations and discussions between countries, United Nations agencies and more than fifty international organizations.

2) ILO Convention No. 182 of 1999 concerning the Prohibition and Immediate Action for the Elimination of Worst Forms of Child Labor (Concerning the Prohibition and Immediate Action for the Elimination of Worst Forms of Child Labor) The ILO is a permanent international organization established by agreement between governments, with the broad goal of creating universal and lasting world peace through the creation of social justice in the labor sector which is often associated with injustice, hardship, and so on. threaten world peace and order. The ILO was established as an autonomous institution associated with the League of Nations (LBB), which was later associated with the United Nations which was signed on 14 December 1946

\subsection{Criminal Liability Against The Criminal Act Of Trafficting Children For The Purpose Of} Prostitution

a. Position Case

1) Chronological

a) That on Thursday, January 24, 2008, if at $15.00 \mathrm{Wib}$, Angel Bulan Agustina was picked up by Ali Akbar Syahbana Panjaitan at his parents' house, Jl. Multatuli No. 43 Medan, to work at a café owned by his older brother, Delvi Panjaitan in Bagan Batu, Riau.

b) Before Ali Akbar Syahbana Panjaitan picked up Angel Bulan Agustina, at least another time was in January 2008, Ali Akbar Syahbana Panjaitan contacted Delvi Panjaitan, "Sis, I have a friend who wants to work, so I offer to work at your café in Bagan Batu, can you do that? ?", he replied, "oh, just bring the deck, it's a good time. Because there are less members here and I have just opened, so that I will have more guests and subscribers."

c) Previously, Ali Akbar Syahbana Panjaitan contacted Delvi, saying to find someone who would work at Delvi Panjaitan's café. 
d) Then Ali Akbar Syahbana Panjaitan with his friends, Idham Nasution and Roynaldo Sihombing came to Angel's house.

Bulan Agustina seduced and promised to be hired as a cafe waitress, then said, "Come on, Angel said he wanted to find a job. Let's go now, Angel. Earlier, I called my sister in Bagan Batu and she was waiting there, later you will work at the café as a drink delivery person, this is a good place, costs are covered."

e) Then Idham Nasution and Roynaldo Sihombing said to Angel, "Come on, Angel, we're also coming, let's go together", so at the words of Ali Akbar Syahbana Panjaitan and Idham Nasution and Roynaldo Sihombing, Angel Bulan Agustina agreed and immediately left and left. from his home without his parents' permission, and they departed by public passenger bus.

f) Arriving at the place, namely Delvi Panjaitan's cafe/barracks, Idham Nasution and Roynaldo Sihombing handed Angel to Delvi, then Delvi said to Angel, "You are only here to accompany guests, and if there are guests who want to use you, just like it, play once. paid Rp. 150,000, - (one hundred and fifty thousand rupiah) and if the guest stayed overnight the fee was Rp. 350,000, - (three hundred and fifty thousand rupiah).

g) Because Angel did not have as much money, he agreed with Delvi's words, then Ali Akbar received a monetary reward of Rp. 100,000, - (one hundred thousand rupiah) from Delvi, for bringing Delvi to work at his café to serve guests having marital relations at the his café in Bagan Batu, Riau.

h) Every time Angel serves guests having marital relations, he pays Delvi IDR 50,000 (fifty thousand rupiah).

i) For Delvi Panjaitan's actions, Angel's parents, namely Ivona br. Gultom objected and complained to the authorities for further processing.

j) Then on Friday 15 February 2008, Angel was sent home by Delvi Panjaitan because Ali Akbar Syahbana Panjaitan had been arrested by the police and the next day on 16 February 2008, Delvi Panjaitan was also arrested.

2) Defendants Indictment

Full name

Place of birth

: DELVI PANJAITAN

Age/ Date. Born

: Medan

Gender

: 33 Years/ July 111974

: Woman

Nationality

: Indonesia

Place of Residence: Medan, Batang Quiz Sei Rattan Dsn II Gg. District dance. Ps. Master/ Borders of the Batu Swallow Crossroads Riau

Religion : Islam

Work : entrepreneur

Education : junior high school

a) Primary Indictment:

Article 2 paragraph (1) of Law no. 21 of 2007 concerning the Eradication of the Crime of Trafficking in Persons, namely: any person who recruits, transports, harbors, sends, transfers, or receives a person by means of threats of violence, use of force, kidnapping, confinement, forgery, fraud, abuse of power or a position of vulnerability, debt bondage or giving payments or benefits despite obtaining approval from a person who has control over another person, for the purpose of exploiting that person in the territory of the Republic of Indonesia, shall be punished with imprisonment for a minimum of 3 (three) years and a maximum of 15 (fifteen) years. and a minimum fine of Rp 120,000,000 (one hundred and twenty million rupiah) and a maximum of Rp 600,000,000 (six hundred million rupiah), in conjunction with Article 55 paragraph (1) 1e of the Criminal Code,

b) Subsidiary Indictment: 
Article 11 of Law no. 21 of 2007 concerning the Eradication of the Criminal Act of Trafficking in Persons, namely: any person who plans or commits a malicious conspiracy to commit a criminal act of trafficking in persons, shall be subject to the same punishment as the perpetrator as referred to in Article 2, Article 3, Article 4, Article 5, and

Article 6.

c) More Subsidiary Indictments:

Article 83 of Law no. 23 of 2002 concerning Child Protection, namely: Everyone who trades, sells, or kidnaps children for himself or for sale, shall be sentenced to a maximum of 15 (fifteen) years in prison and a minimum of 3 (three) years and a maximum fine of Rp. 300,000. .000, - (three hundred million rupiah) and at least Rp. 60,000,000 (sixty million rupiah).

b. Legal Facts testimony of witnesses, under oath before the court explained as follows:

1) Ivona Gultom. That is true, the witness knew that the witness who brought the witness's child was Ali Akbar Syahabana Panjaitan because previously the victim witness had told the witness that he would be invited to go to Bagan Batu, Riau for work but the witness did not allow it.

2) Angel Bulan Agustina (Witness Victim). That is true, the victim witness was invited by Ali Akbar Syahbana Panjaitan to work at a café owned by his brother, the defendant Delvi Panjaitan in Bagan Batu, Riau.

3) Idham Nasution. That is true, Ali Akbar Syahbana Panjaitan's intention to invite the victim's witness was to work at a cafe owned by Ali Akbar Syahbana Panjaitan's older brother, namely Delvi Panjaitan as a cafe waiter.

4) Roynaldo Sihombing. That it is true that on Thursday, January 24, 2008 at around 17.00 Wib Ali Akbar Syahbana Panjaitan picked up the victim's witness on Jl. Multatuli Medan to be invited to Bagan Batu, Riau. That is true, Ali Akbar Syahbana Panjaitan's intention to invite the victim's witness was to work at a cafe owned by Ali Akbar Syahbana Panjaitan's older brother, namely Delvi Panjaitan as a cafe waiter.

5) Erika Marpaung. That it is true that on Thursday, January 24, 2008 at around $17.00 \mathrm{Wib}$ Ali Akbar Syahbana Panjaitan picked up the victim's witness on Jl. Multatuli Medan to be invited to Bagan Batu, Riau. That is true, Ali Akbar Syahbana Panjaitan's intention to invite the victim's witness was to work at a cafe owned by Ali Akbar Syahbana Panjaitan's older brother, namely Delvi Panjaitan as a cafe waiter. That is true, the witness went along with Ali Akbar Syahbana Panjaitan to Bagan Batu, Riau to escort the victim witness. That is true, the witness did not know that the victim witness was employed in a café owned by the defendant Delvi Panjaitan to serve the lusts of masher. That is true, the witness went along with Ali Akbar Syahbana Panjaitan to Bagan Batu, Riau to escort the victim witness. That is true, when they arrived at Bagan Batu, Riau, the victim's witness was ordered by the defendant to serve the lust of a masher. That is true, in serving the lust of masher, the victim witness will receive a monetary reward of Rp. 150,000 (one hundred and five thousand rupiah).

c. Letter

Whereas according to the results of Visum Et Repertum No. 112/ OBG/ 2008 dated February 19, 2008 from the General Hospital dr. Pirngadi Medan on behalf of Angel Bulan Agustina obtained the results of the examination: External genitals: - Hymen (hymen) torn long to the bottom at 5 (five), 7 (seven) o'clock; Inner genitals: - Ordinary large uterus.

d. Instruction

There is a discrepancy between the statements of the witnesses and the results of the Visum Et Repertum No. 112/ OBG/ 2008 dated February 19, 2008 on behalf of Angel Bulan Agustina from the Hospital.

Defendant's Statement, under oath before the court explained as follows:

1) That it is true that on Thursday, January 24, 2008 at approximately $15.00 \mathrm{Wib}$ at Jl. Multatuli No. 43 Medan, witness Ali Akbar Syahbana Panjaitan visited victim witness 
Angel Bulan Agustina to be invited to work at the defendant's café in Bagan Batu as a waitress. And because they were lured to work only as a cafe waiter and the costs were borne, finally the victim witness Angel Bulan Agustina wanted to go to Bagan Batu Riau even without the consent of the victim's parents.

2) That it is true that when he arrived at Bagan Batu Riau, precisely at the defendant's café, witness Ali Syahbana Panjaitan then handed the victim's witness to the defendant who then the defendant said to the victim's witness, "You are only here to accompany guests and if anyone wants to use you, it's okay, just once. playing Rp 150,000, - (one hundred and fifty thousand rupiah) and if the guest stays overnight the fee is $\mathrm{Rp}$ 350,000, - (three hundred and fifty thousand rupiah).

3) That it is true that because the victim's witness did not have money, the victim's witness agreed with the defendant's words.

4) That it is true that witness Ali Akbar Syahbana Panjaitan received a cash reward of Rp 100,000 (one hundred thousand rupiah) from the defendant for bringing the victim to work at the defendant's place.

5) That it is true that every time he gets a guest, the victim witness must give the defendant Rp 50,000 (fifty thousand) money.

6) That is true for the defendant's actions, the parents of the victim's witness objected and complained the defendant to the authorities.

7) That it is true that on Friday 15 February 2008, Angel was sent home by Delvi Panjaitan because Ali Akbar Syahbana Panjaitan had been arrested by the police and the next day, 16 February 2008, the defendant was also arrested.

e. Criminal Lawsuit

The Prosecutor in his Requisatoir was of the opinion that the Defendant Delvi Panjaitan was proven guilty of having committed a "criminal act" as charged in the Primary Indictment, namely Article 2 of Law no. 21 of 2007 concerning Eradication of the Crime of Trafficking in Persons in conjunction with Article 55 paragraph (1) 1e of the Criminal Code and demands that the defendant be sentenced to 10 (ten) years in prison and a fine of Rp. 120,000,000 (one hundred and twenty million rupiah) subsidiary of 2 (two) months of confinement.

f. Decision

The judge at the Medan District Court who tried this case gave a decision stating that the defendant's act of trafficking in minors was a crime: "Child Trafficking Crime" as charged in the Primary Indictment regulated in Article 2 of Law No. . 21 of 2007 concerning Eradication of the Crime of Trafficking in Persons in conjunction with Article 55 paragraph (1) 1e of the Criminal Code and demands that the defendant be sentenced to: 8 (eight) years in prison and a fine of Rp. 120,000,000 (one hundred and twenty million rupiah) subsidiary of 2 (two) months of confinement.

\section{Conclusion}

From the description of "Criminal Accountability Against Actors of the Crime of Child Trafficking for the Purpose of Prostitution", it can be concluded from the literature review and review to the Medan District Court, as follows. The regulations relating to child trafficking are:

a. National legal regulations, namely:

1) Criminal Code (KUHP)

The Criminal Code is no longer used, because the articles relating to child trafficking are no longer in accordance with the current development of society so that they cannot ensnare traffickers.

2) Law No. 39 of 1999 concerning Human Rights

3) Law No. 23 of 2003 concerning Child Protection

4) Regional Regulation of North Sumatra Province No. 6 of 2004 concerning the Elimination of Trafficking in Women and Children Since the promulgation of Law 
no. 21 of 2007 concerning Eradication of the Crime of Trafficking in Persons, the provisions regarding criminal sanctions refer to the law.

5) Law No. 21 of 2007 concerning Eradication of the Crime of Trafficking in Persons

6) International legal regulations, namely: 1989 Convention on the Rights of the Child and ILO Convention No. 182 of 1999 concerning the Prohibition and Immediate Action for the Elimination of Worst Forms of Child Labor (Concerning the Prohibition and Immediate Action for the Elimination of Worst Forms of Child Lobour)

b. Criminal liability for perpetrators of the crime of trafficking in children for the purpose of prostitution in Case Register No. 1.262/ Pid. B/ 2008/ PN. Mdn, has complied with the applicable regulations. The concept of accountability is the same as the concept of punishment in general, where a person can be held accountable if he has made a mistake. In the application of the provisions of the regulations used must also be based on the tempus delicti. This means that the provisions applied to the perpetrator are seen from when the criminal event occurred, so that it is in accordance with the principle of legality.

\section{References}

Adami Chazawi, 2002, Criminal Law Lessons Part 1. First Issue. PT. RajaGrafindo Persada, Jakarta.

ACILS - ICMC - USAID, 2003, Guidelines for Handling Children Victims of Human Trafficking, Child Rights Advocacy Institute, Bandung.

Andi Hamzah, 1994, Principles of Criminal Law, Ribeka Cipta, Jakarta.

Apong Herlina; Ernanti Wahyunrini; et al, 2003, Child Protection Based on Law Number 23 of 2002 concerning Child Protection, UNICEF Indonesia, Harapan Prima, Indonesia.

B. Simanjuntak, 1981, Some Aspects of Social Pathology, Alumni, Bandung.

Chairul Bahriah, 2005, Trafficking Laws: Trafficking of Women and Children, Issue I, USU Press Publisher, Medan.

ECPAT International, 2006, Q\&A on Commercial Sexual Exploitation of Children, Restu PrintingIndonesia.

EY Kanter, SR Sianturi, 2002, Principles of Criminal Law in Indonesia and Its Application. Storia Graphics, Jakarta.

MOCH'S RIGHTS. Anwar, 1980, Criminal Law Special Section (KUHP Book II), Alumni, Bandung.

Hull, T., Sulistyaningsih, E., and Jones, GW, 1997, Prostitution in Indonesia: Its History and Development, Sinar Harapan Pustaka and Ford Foundation, Jakarta.

JS Badudut and Sutan Mohammad Zain, 2001, General Indonesian Dictionary, Sinar Harapan Library, Jakarta.

Kartini Kartono, 1986, Social Pathology, Raja Grafindo Persada, Jakarta Coordinating Ministry for People's Welfare, 2005, Elimination.

Trafficking in Persons in Indonesia 2004-2005, Jakarta.

National Coalition for the Elimination of Commercial Sexual Exploitation of Children, ECPAT Affiliate Group in Indonesia, 2008, Against Pornography and Exploitation of Children, National Coalition of PESKA, Medan. 
Leden Marpaung, 1996, Crimes against Morality and the Problem of its Prevention, Sinar Graphic, Jakarta.

Moeljatno, 2002, Principles of Criminal Law, Rineka Cipta, Jakarta.

Moh. Joni and Zulchaina Z. Tanamas, 1999, Legal Aspects of Child Protection in the Perspective of the Convention on the Rights of the Child. Publisher PT. Citra Aditya Bakti, Bandung.

Zainal Abidin Farid, 1995, Criminal Law I, Sinar Graphic, Jakarta.

Law No. 39 of 1999 concerning Human Rights Law no. 23 of 2002 concerning Child Protection.

Law No. 21 of 2007 concerning Eradication of the Crime of Trafficking in Persons

Regional Regulation of North Sumatra Province No. 6 of 2004 concerning the Elimination of Trafficking in Women and Children.

Convention on the Rights of the Child 1989 (Convention on The Right of The Child 1989).

ILO Convention No. 182 of 1999 concerning the Prohibition and Immediate Action for the Elimination of Worst Forms of Child Labor (Concerning the Prohibition and Immediate Action for the Elimination of Worst Forms of Child Labor).

Protocol to the Convention on the Rights of the Child on Trafficking in Children, Child Prostitution and Child Pornography 2002.

Muhammad Joni, 2006, "Eradication of the Crime of Trafficking in Persons and Protection of Victims", published in the Pledoi Trafficking in Person Magazine, Pusaka Indonesia, Vol. I No. April 1, 2006 